\title{
Phenoxazine-Based Emissive Donor-Acceptor Materials for Efficient Organic Light Emitting Diodes
}

\author{
Yan Zhu, Abhishek P. Kulkarni and Samson A. Jenekhe*
}

Department of Chemical Engineering and Department of Chemistry, University of Washington,

Seattle, Washington 98195-1750

\section{Supporting Information}

Materials. Phenoxazine, iodomethane $\left(\mathrm{CH}_{3} \mathrm{I}\right)$, iodobenzene, copper, sodium hydride $(60 \%$ in mineral oil), anhydrous tetrahydrofuran (THF), aluminum chloride, acetyl chloride, anhydrous carbon disulfide $\left(\mathrm{CS}_{2}\right), \quad m$-cresol, 2-aminobenzophenone, triethylamine, methanol, diphenylphosphate (DPP) were obtained from Aldrich and used as received.

10-Phenylphenoxazine (3a). This compound was prepared by following a reported method with a modified purification procedure. ${ }^{1}$ In a flask were mixed $10 \mathrm{~g}(55 \mathrm{mmol})$ of phenoxazine, $14.7 \mathrm{~g}(72 \mathrm{mmol})$ of iodobenzene, $7.6 \mathrm{~g}$ of potassium carbonate and $0.44 \mathrm{~g}$ of copper powder. This mixture was heated to $200{ }^{\circ} \mathrm{C}$ for $72 \mathrm{~h}$ and then cooled to room temperature. The mixture was dissolved in $\mathrm{CH}_{2} \mathrm{Cl}_{2}$, washed with $5 \%$ hydrochloric acid followed by water, dried and concentrated. The crude product was purified by flash column chromatography (silica gel, toluene), followed by recrystallization from benzene to afford compound $\mathbf{3 a}(10.7 \mathrm{~g})$ as white needles with $76 \%$ yield, m.p. $138.5-139.1{ }^{\circ} \mathrm{C}$ (lit. 138-139 $\left.{ }^{\circ} \mathrm{C}\right) .{ }^{1}{ }^{1} \mathrm{H}$ NMR $\left(300 \mathrm{MHz}, \mathrm{CDCl}_{3}\right)$ : $\delta$ $7.61(\mathrm{t}, 2 \mathrm{H}), 7.47(\mathrm{t}, 1 \mathrm{H}), 7.36(\mathrm{~d}, 2 \mathrm{H}), 6.57-6.73(\mathrm{~m}, 6 \mathrm{H}), 5.93(\mathrm{~d}, 2 \mathrm{H})$. GC-MS showed the presence of only one component with $m / z 259$.

10-Methylphenoxazine (3b). This compound was prepared by following a reported $\operatorname{method}^{1}$ with a modified procedure. In a flame-dried flask, $10 \mathrm{~g}(55 \mathrm{mmol})$ of phenoxazine was dissolved in $150 \mathrm{~mL}$ of anhydrous THF under argon. The clear solution was cooled to $0-5{ }^{\circ} \mathrm{C}$ 
with an ice-water bath. $2.4 \mathrm{~g}$ of sodium hydride (60\% in mineral oil, $60 \mathrm{mmol})$ was added and the resulting solution was stirred for $2 \mathrm{~h}$ before a THF solution containing $\mathrm{CH}_{3} \mathrm{I}(11.7 \mathrm{~g}, 82.5$ mmol) was added dropwise. The ice-water bath was removed and the solution was allowed to stir for $10 \mathrm{~h}$. The reaction was then quenched with $200 \mathrm{~mL}$ of water and the solution was extracted with methylene chloride $(3 \times 100 \mathrm{~mL})$. The combined organic layers were dried over anhydrous sodium sulfate and the solvent was removed by rotary evaporation. The crude product was purified by silica gel column chromatography with hexane as eluent. $9.3 \mathrm{~g}$ of clear viscous liquid which solidified on chilling to give a semi-solid was obtained with $86 \%$ yield. ${ }^{1} \mathrm{H}$ NMR (300 $\left.\mathrm{MHz}, \mathrm{CDCl}_{3}\right): \delta 6.62-6.96(\mathrm{~m}, 8 \mathrm{H}), 3.11(\mathrm{~s}, 3 \mathrm{H})$. GC-MS showed the presence of only one component with $m / z 197$.

3,7-Diacetyl-10-phenylphenoxazine (4a). This compound was synthesized by FriedelCrafts acylation with acetic anhydride. ${ }^{2}$ To a dispersion of $18.1 \mathrm{~g}(0.136 \mathrm{~mol})$ of anhydrous $\mathrm{AlCl}_{3}$ in $50 \mathrm{~mL}$ of $\mathrm{CS}_{2}$ was added slowly a $100 \mathrm{~mL} \mathrm{CS}$ solution containing $9.05 \mathrm{~g}(0.089 \mathrm{~mol})$ of acetic anhydride and $8.5 \mathrm{~g}(0.033 \mathrm{~mol})$ of $\mathbf{3 a}$ at $0{ }^{\circ} \mathrm{C}$ under argon atmosphere. The reaction mixture was stirred for $36 \mathrm{~h}$ at room temperature and poured into ice-water followed by the addition of $80 \mathrm{~mL}$ of $3 \mathrm{M} \mathrm{HCl}$ aqueous solution with vigorous stirring. The aqueous solution was extracted with $\mathrm{CH}_{2} \mathrm{Cl}_{2}$ three times. The combined organic layer was washed successively with pure water, $10 \%$ aqueous $\mathrm{NaHCO}_{3}$, pure water again, and dried over anhydrous $\mathrm{Na}_{2} \mathrm{SO}_{4}$. After the solvent was evaporated, the residue was purified by silica gel column chromatography with toluene/ethyl acetate $(9 / 1, \mathrm{v} / \mathrm{v})$ as eluent. Recrystallization from toluene twice gave $7.9 \mathrm{~g}(70 \%)$ of 4a as yellow needles, m.p. 230.8-231.6 ${ }^{\circ} \mathrm{C} .{ }^{1} \mathrm{H}$ NMR $\left(300 \mathrm{MHz}, \mathrm{CDCl}_{3}\right): \delta 7.67(\mathrm{t}, 2 \mathrm{H}), 7.57$ $(\mathrm{t}, 1 \mathrm{H}), 7.24-7.36(\mathrm{~m}, 6 \mathrm{H}), 5.95(\mathrm{~d}, 2 \mathrm{H}), 2.48(\mathrm{~s}, 6 \mathrm{H})$. GC-MS showed the presence of only one component with $m / z 343$. 
3,7-Diacetyl-10-methylphenoxazine (4b). This compound was synthesized by FriedelCrafts acylation with acetyl chloride. ${ }^{3}$ To a solution of $10 \mathrm{~g}(0.051 \mathrm{~mol})$ of $\mathbf{3 b}$ and $20.3 \mathrm{~g}(0.152$ mol) of $\mathrm{AlCl}_{3}$ in $180 \mathrm{~mL}$ of $\mathrm{CS}_{2}$ was added $11.9 \mathrm{~g}(0.152 \mathrm{~mol})$ of acetyl chloride dropwise under argon atmosphere. The reaction mixture was stirred for $24 \mathrm{~h}$ at $45{ }^{\circ} \mathrm{C}$ and poured into ice-water followed by the addition of $100 \mathrm{~mL}$ of $3 \mathrm{M} \mathrm{HCl}$ aqueous solution with vigorous stirring. The aqueous solution was extracted with $\mathrm{CH}_{2} \mathrm{Cl}_{2}$. The combined organic layer was washed with pure water, $10 \%$ aqueous $\mathrm{NaHCO}_{3}$, pure water again, and dried over anhydrous $\mathrm{Na}_{2} \mathrm{SO}_{4}$. After the solvent was evaporated, the residue was purified by silica gel column chromatography with hexane/ethyl acetate $(1 / 1, \mathrm{v} / \mathrm{v})$ as eluent. Recrystallization from ethanol gave $10.7 \mathrm{~g}(75 \%)$ of $\mathbf{4 b}$ as orange powder, m.p. 178.6- $179.4{ }^{\circ} \mathrm{C} .{ }^{1} \mathrm{H}$ NMR $\left(300 \mathrm{MHz}, \mathrm{CDCl}_{3}\right): \delta 7.53(\mathrm{~d}, 2 \mathrm{H}), 7.28(\mathrm{~s}$, $2 \mathrm{H}), 6.59(\mathrm{~d}, 2 \mathrm{H}), 3.17(\mathrm{~s}, 3 \mathrm{H}), 2.50(\mathrm{~s}, 6 \mathrm{H})$. GC-MS showed the presence of only one component with $m / z 281$.

10-Phenyl-3,7-bis-(4-phenyl-quinolin-2-yl)-10H-phenoxazine $\quad$ (BPQ-PPO, 5a). 2Aminobenzophenone $(1.38 \mathrm{~g}, 7.00 \mathrm{mmol})$ and $4 \mathrm{a}(1.00 \mathrm{~g}, 2.92 \mathrm{mmol})$ were added along with $9 \mathrm{~g}$ of DPP and $6 \mathrm{~g}$ of $m$-cresol in a flask. The reaction mixture was purged with argon for $20 \mathrm{~min}$, and then the temperature was gradually raised to $90{ }^{\circ} \mathrm{C}$ for $1 \mathrm{~h}$ and then to $140{ }^{\circ} \mathrm{C}$ for $16 \mathrm{~h}$ under argon atmosphere. After cooling, the product was precipitated in a solution of $360 \mathrm{~mL}$ of methanol/40 $\mathrm{mL}$ of triethylamine. The yellow powder was extracted with $10 \%$ triethylamine/methanol solution for 2 days. Recrystallization from benzene gave $\mathbf{5 a}$ as yellow plates $(87 \%) .{ }^{1} \mathrm{H}$ NMR $\left(300 \mathrm{MHz}, \mathrm{CDCl}_{3}\right): \delta 8.22(\mathrm{~d}, 2 \mathrm{H}), 7.89(\mathrm{~d}, 2 \mathrm{H}), 7.66-7.75(\mathrm{~m}, 8 \mathrm{H})$, 7.43-7.58 (m, 17H), 6.09 (d, 2H). FT-IR (KBr pellet, $\left.\mathrm{cm}^{-1}\right)$ : 3059, 1588, 1544, 1505, 1429, 1357 , 1289, 1131, 1072, 1024, 876, 838, 812, 768, 700, 619. MS (ESI mode): Found M+1, 666.5. $\mathrm{C}_{48} \mathrm{H}_{31} \mathrm{~N}_{3} \mathrm{O}$ requires $\mathrm{M}, 665.25$. 
Single crystal of BPQ-PPO was grown by slow evaporation of solvent from benzene solution. The detailed crystallographic data is collected in Table S2.

10-Methyl-3,7-bis-(4-phenyl-quinolin-2-yl)-10H-phenoxazine (BPQ-MPO，5b). This compound was prepared by a procedure similar to that of $\mathbf{5 a}$ except that $\mathbf{4 b}$ was used as reactant instead of 4a. The product was purified by column chromatography (silica gel, $2 \%$ ethyl acetate $/ \mathrm{CH}_{2} \mathrm{Cl}_{2}$ ), followed by recrystallization from benzene to afford $\mathbf{5 b}$ as orange powder with $79 \%$ yield. ${ }^{1} \mathrm{H}$ NMR $\left(300 \mathrm{MHz}, \mathrm{CDCl}_{3}\right): \delta 8.23(\mathrm{~d}, 2 \mathrm{H}), 7.90(\mathrm{~d}, 2 \mathrm{H}), 7.70-7.79(\mathrm{~m}, 8 \mathrm{H}), 7.43-$ $7.58(\mathrm{~m}, 12 \mathrm{H}), 6.70(\mathrm{~d}, 2 \mathrm{H}), 3.22(\mathrm{~s}, 3 \mathrm{H})$. FT-IR $\left(\mathrm{KBr}\right.$ pellet, $\left.\mathrm{cm}^{-1}\right): 3057,2925,1632,1589$ $1540,1511,1456,1371,1293,1242,1152,1113,857,804,765,700,577$. MS (ESI mode): Found $\mathrm{M}+1,604.5 . \mathrm{C}_{43} \mathrm{H}_{29} \mathrm{~N}_{3} \mathrm{O}$ requires $\mathrm{M}, 603.23$.

Single crystal of BPQ-MPO was grown by slow evaporation of solvent from THF solution. The detailed crystallographic data is collected in Table S2.

Characterization. FT-IR spectra were taken on a Perkin Elmer 1720 FTIR spectrophotometer with $\mathrm{KBr}$ pellets. ${ }^{1} \mathrm{H}$ NMR spectra were recorded on a Bruker-AV301 spectrometer at $300 \mathrm{MHz}$. GC-MS spectra were obtained on a Hewlett Packard 5971 GC / Mass Spectometer or Bruker Esquire LC / Ion Trap Mass Spectrometer. Melting points were determined on an Electrothermal IA9100 digital melting point instrument at a heating rate of 1 ${ }^{\circ} \mathrm{C} /$ min. Differential scanning calorimetry (DSC) analysis was performed on a TA instrument Q100 under $\mathrm{N}_{2}$ at a heating rate of $10{ }^{\circ} \mathrm{C} / \mathrm{min}$. Thermogravimetric analysis (TGA) analysis was conducted with a TA instrument Q50 at a heating rate of $20^{\circ} \mathrm{C} / \mathrm{min}$ under a nitrogen gas flow.

Cyclic voltammetry experiments were done on an EG\&G Princeton Applied Research Potentiostat/Galvanostat (Model 273A). Data were collected and analyzed by the Model 270 Electrochemical Analysis System Software on a PC computer. A three-electrode cell was used in 
all experiments. Platinum wire electrodes were used as both counter and working electrodes and silver/silver ion ( $\mathrm{Ag}$ in $0.1 \mathrm{M} \mathrm{AgNO}_{3}$ solution, Bioanalytical System, Inc.) was used as a reference electrode. The $\mathrm{Ag} / \mathrm{Ag}^{+}\left(\mathrm{AgNO}_{3}\right)$ reference electrode was calibrated at the beginning of the experiments by running cyclic voltammetry on ferrocene as the internal standard. The potential values obtained in reference to $\mathrm{Ag} / \mathrm{Ag}^{+}$electrode were then converted to the saturated calomel electrode (SCE) scale. Solution cyclic voltammetry was carried out in a $1 \mathrm{mM}$ solution of the compound in a mixed benzene/acetonitrile $(2: 1 \mathrm{v} / \mathrm{v})$ solvent containing $\operatorname{TBAPF}_{6}(0.1 \mathrm{M})$ as an electrolyte. All solutions were purged with high-purity $\mathrm{N}_{2}$ for 15-20 minutes before each experiment and a blanket of $\mathrm{N}_{2}$ was used during the experiment.

UV-vis absorption spectra were recorded on a Perkin-Elmer model Lambda 900 UV/vis/near-IR spectrophotometer. The photoluminescence (PL) emission spectra were obtained with a Photon Technology International (PTI) Inc. model QM-2001-4 spectrofluorimeter. The PL quantum yields of the D-A molecules in dilute $\left(5 \times 10^{-6} \mathrm{M}\right)$ toluene solution were measured by using a $5 \times 10^{-6} \mathrm{M}$ solution of 9,10-diphenylanthracene in toluene as standard $\left(\phi_{\mathrm{PL}}=93 \%\right) .{ }^{4}$ All solutions were degassed with nitrogen for at least 15-20 min before spectral acquisition.

Fabrication and Characterization of OLEDs. We fabricated two types of OLEDs, singlelayer and bilayer, with the BPQ-PPO and BPQ-MPO D-A molecules. A 50-nm thick poly(ethylenedioxythiophene) / poly(styrene sulfonate) blend (PEDOT) hole-injection layer was used in the bilayer devices. The two types of devices are: ITO/D-A/LiF/Al and ITO/PEDOT/TAPC/D-A/LiF/Al. ITO-coated glass substrates (Delta Technologies Ltd., Stillwater, MN) were cleaned sequentially in ultrasonic bathes of 2-propanol/deionized water (1:1 volume) mixture, toluene, deionized water and acetone, and then dried at $60{ }^{\circ} \mathrm{C}$ in a vacuum overnight. For the single-layer diodes, 45-nm thick films of the D-A molecules were obtained 
directly on ITO by evaporation from resistively heated quartz crucibles at a rate of $\sim 0.3-0.5 \mathrm{~nm} / \mathrm{s}$ in a vacuum evaporator (Edwards Auto 306) at base pressures of $<3 \times 10^{-6}$ Torr. The chamber was vented with air to load the cathode materials, pumped back down and then a $2-\mathrm{nm} \mathrm{LiF}$ and a 110-nm thick aluminum layer were sequentially deposited through a shadow mask on top of the D-A film without breaking vacuum to form active diode areas of $0.2 \mathrm{~cm}^{2}$. For the bilayer OLEDs, a 50-nm thick hole injection layer of PEDOT was spin-coated on top of ITO from a $\sim 1$ wt $\%$ dispersion in water and dried at $200{ }^{\circ} \mathrm{C}$ for 15 min under a vacuum. Before spin-coating, the PEDOT solution was filtered through $0.45 \mu \mathrm{m}$ PVDF syringe filters. The TAPC (35 nm) holetransport/electron-blocking layer was obtained by spin-coating on top of PEDOT from $1.5 \mathrm{wt} \%$ solution in toluene and dried in a vacuum at $60{ }^{\circ} \mathrm{C}$ overnight. Before spin-coating, the solutions were filtered through $0.2 \mu \mathrm{m}$ PTFE syringe filters. The film thicknesses were measured by an Alpha-Step 500 surface profiler (KLA Tencor, Mountain View, CA). Thin films of the D-A molecules $(45 \mathrm{~nm})$ were evaporated on the TAPC layers, the chamber was vented and then LiF and $\mathrm{Al}$ were sequentially deposited as described above.

Electroluminescence spectra were obtained using a PTI QM-2001-4 spectrophotometer. Current-voltage characteristics of the LEDs were measured using a HP4155A semiconductor parameter analyzer (Yokogawa Hewlett-Packard, Tokyo). The luminance was simultaneously measured using a model 370 optometer (UDT instruments, Baltimore, MD) equipped with a calibrated luminance sensor head (model 211) and a 5x objective lens. The device external quantum efficiencies were calculated using procedures reported previously. ${ }^{5}$ All the device fabrication and characterization steps were done under ambient laboratory conditions. 


\section{References}

1. Gilman, H.; Moore, L. O. J. Am. Chem. Soc. 1957, 79, 3485.

2. Morishima, Y.; Nomura, S.; Kamachi, M. J. Polym. Sci. Part A: Polym. Chem. 1994, 32, 3141.

3. Lai, R. Y.; Fabrizio, E. F.; Lu, L.; Jenekhe, S. A.; Bard, A. J. J. Am. Chem. Soc. 2001, 123, 9112.

4. Heinrich, G.; Schoof, S.; Gusten, H. J. Photochem. 1974, 3, 315.

5. (a) Okamoto, S.; Tanaka, K.; Izumi, Y.; Adachi, H.; Yamaji, T.; Suzuki, T. Jpn. J. Appl. Phys.

2001, 40, L783. (b) Kulkarni, A. P.; Jenekhe, S. A. Macromolecules 2003, 36, 5285.

Table S1. Device Characteristics of OLEDs: ITO/PEDOT/TAPC (35 nm)/D-A (45 nm)/LiF/Al ${ }^{\mathrm{a}}$

\begin{tabular}{cccccccc}
\hline $\begin{array}{c}\text { D-A } \\
\text { Molecule }\end{array}$ & $\begin{array}{c}\mathrm{V}_{\text {on }}^{\mathrm{b}} \\
(\mathrm{V})\end{array}$ & $\begin{array}{c}\text { Drive } \\
\text { Voltage } \\
(\mathrm{V})\end{array}$ & $\begin{array}{c}\mathrm{J}^{\mathrm{c}} \\
(\mathrm{mA} / \\
\left.\mathrm{cm}^{2}\right)\end{array}$ & $\begin{array}{c}\mathrm{L}^{\mathrm{d}} \\
(\mathrm{cd} / \\
\left.\mathrm{m}^{2}\right)\end{array}$ & $\begin{array}{c}\text { Device Efficiency } \\
\left(\mathrm{cd} / \mathrm{A}, \% \mathrm{EQE},{ }^{\mathrm{e}} / \mathrm{lm} / \mathrm{W}\right)\end{array}$ & $\begin{array}{c}\text { fwhm }^{\mathrm{f}} \\
(\mathrm{nm})\end{array}$ & $\begin{array}{c}\text { CIE 1931 } \\
(\mathrm{x}, \mathrm{y})^{\mathrm{g}}\end{array}$ \\
\hline BPQ-PPO & \multirow{2}{*}{3.0} & 9.2 & 355 & 9510 & $\begin{array}{c}2.68,0.86,0.92 \\
3.42,1.10,1.28\end{array}$ & 53 & $(0.20,0.58)$ \\
BPQ-MPO & 3.0 & 9.0 & 418 & 4520 & $1.08,0.31,0.38$ & & \\
& & 7.8 & 98 & 1645 & $1.68,0.47,0.68$ & 68 & $(0.31,0.62)$
\end{tabular}

${ }^{\mathrm{a}}$ Values in italic correspond to those for maximum device efficiencies at a practical brightness of at least $\geq 100 \mathrm{~cd} / \mathrm{m}^{2}$. ${ }^{\mathrm{b}}$ Turn-on voltage (at which EL is visible to the eyes). ${ }^{\mathrm{c}}$ Current Density. ${ }^{\mathrm{d}}$ Luminance. ${ }^{\mathrm{e}} \mathrm{EQE}=$ External Quantum Efficiency. ${ }^{\mathrm{f}}$ Full width at half-maximum of EL emission spectra at maximum brightness. ${ }^{\mathrm{g}}$ At maximum brightness. 
Table S2. Crystallographic data for BPQ-PPO (5a) and BPQ-MPO (5b).

\begin{tabular}{|c|c|c|}
\hline & BPQ-PPO (5a) & BPQ-MPO (5b) \\
\hline Formula & $\mathrm{C}_{54} \mathrm{H}_{37} \mathrm{~N}_{3} \mathrm{O}$ & $\mathrm{C}_{51} \mathrm{H}_{45} \mathrm{~N}_{3} \mathrm{O}_{3}$ \\
\hline Formula weight & 743.87 & 747.90 \\
\hline Crystal system & Monoclinic & Monoclinic \\
\hline Crystal description/color & Plate/yellow & Prism/yellow \\
\hline Space group & $\mathrm{C} 2 / \mathrm{c}$ & $\mathrm{P} 21 / \mathrm{c}$ \\
\hline 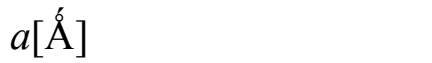 & $27.3440(10)$ & $17.5300(10)$ \\
\hline$b[\AA ̊ d]$ & $9.7620(3)$ & $8.1310(5)$ \\
\hline$c[\AA ̊ \AA]$ & $30.2730(11)$ & $30.8010(19)$ \\
\hline$\beta(\operatorname{deg})$ & $94.2270(18)$ & $119.927(2)$ \\
\hline Volume $\left[\AA^{3}\right]$ & $8058.9(5)$ & $3804.9(4)$ \\
\hline Temperature [K] & 130 & 130 \\
\hline$Z$ & 8 & 4 \\
\hline$R_{1}$ & 0.0562 & 0.0781 \\
\hline$R_{\mathrm{W}}$ & 0.1142 & 0.1958 \\
\hline GOF & 0.938 & 0.998 \\
\hline
\end{tabular}




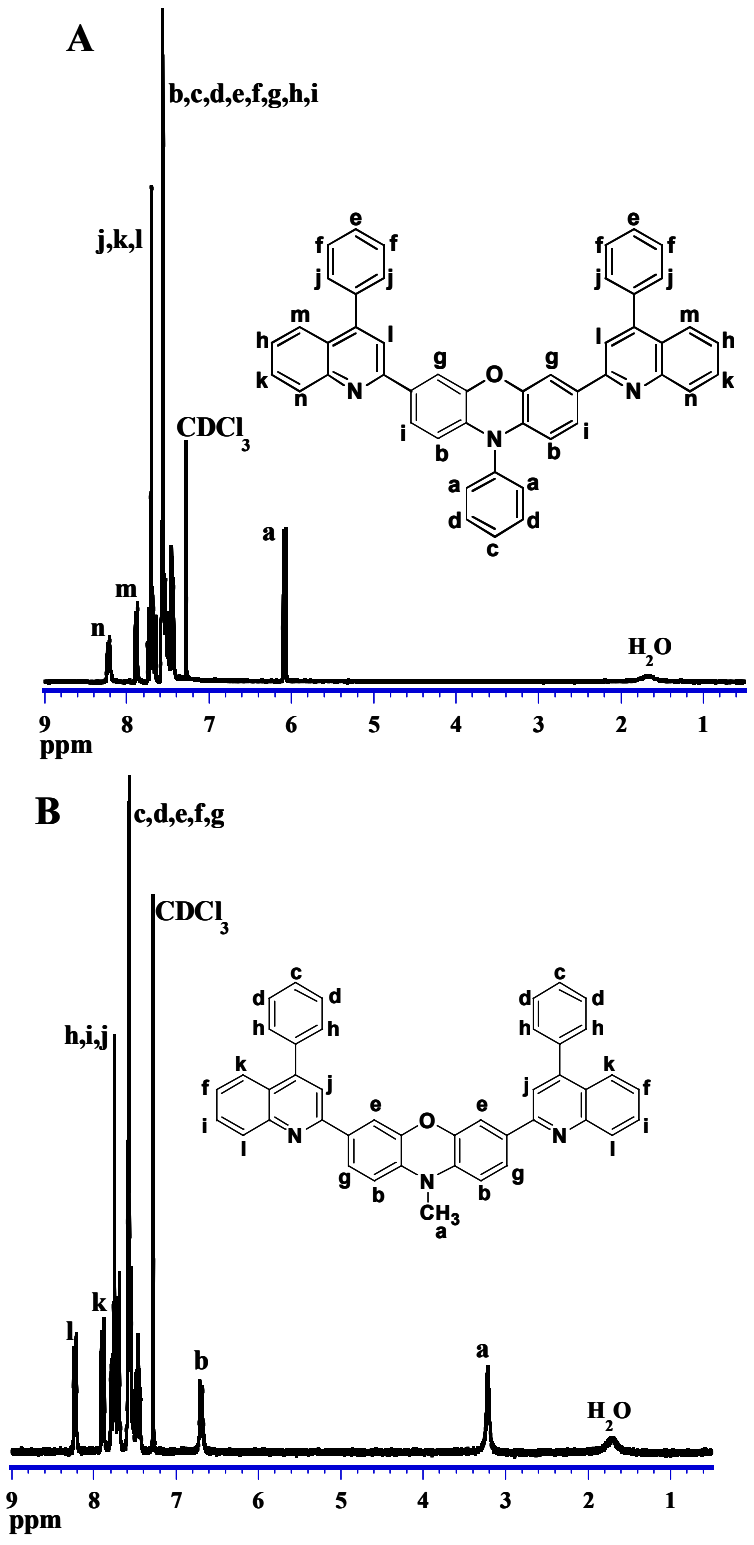

Figure S1. ${ }^{1} \mathrm{H}$ NMR spectra of (A) BPQ-PPO and (B) BPQ-MPO in $\mathrm{CDCl}_{3}$. 


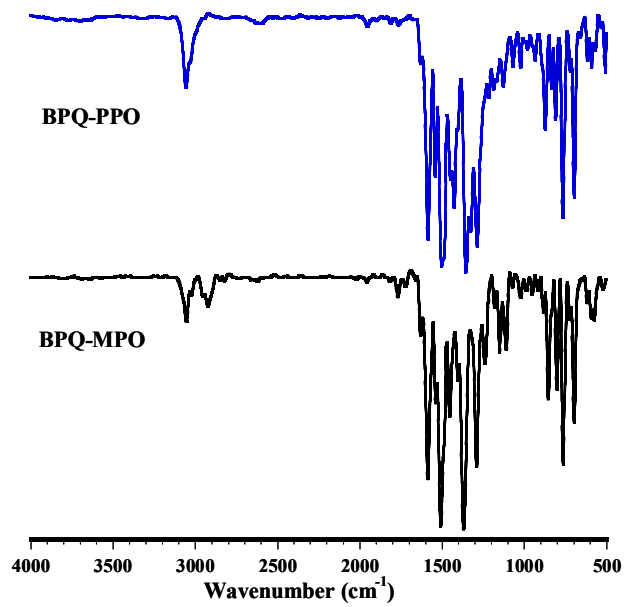

Figure S2. FT-IR spectra of BPQ-PPO and BPQ-MPO.
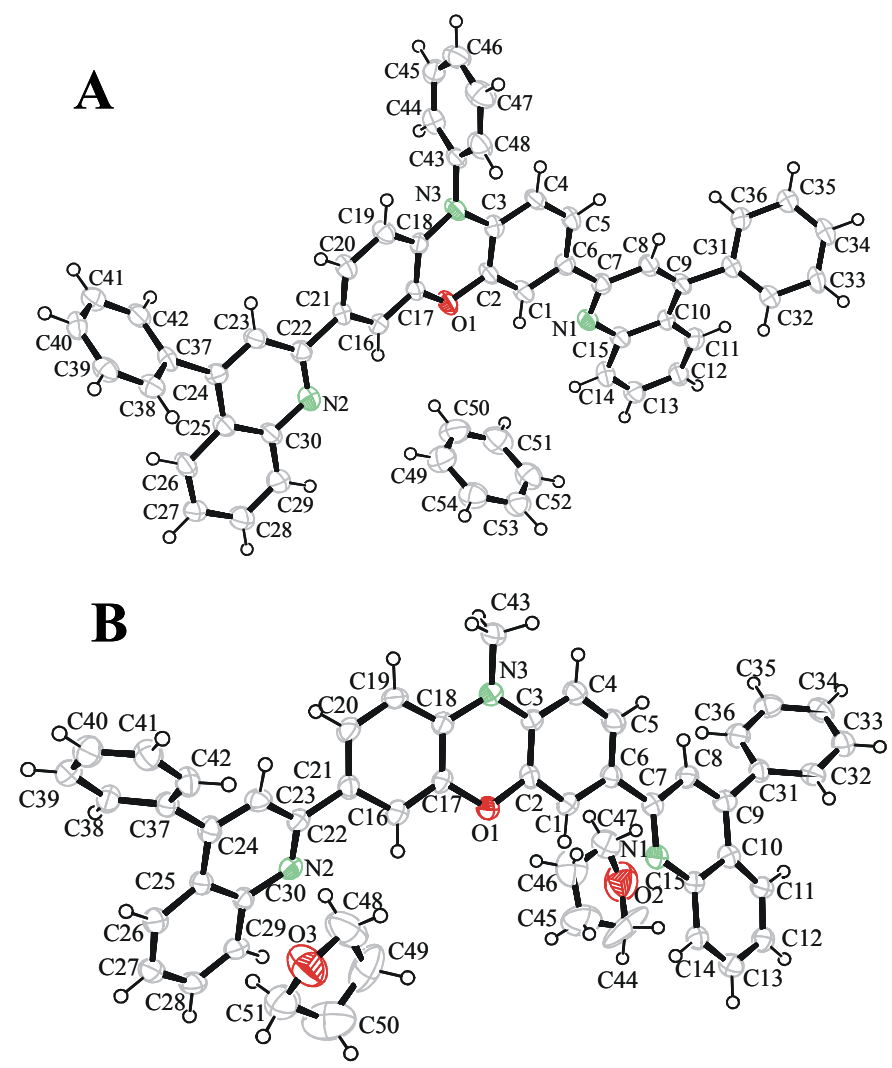

Figure S3. ORTEP diagram of (A) 5a and (B) 5b. Thermal ellipsoids are shown at their $50 \%$ probability volume. Solvent molecules, benzene and THF, that fills voids in the unit cell were found. 

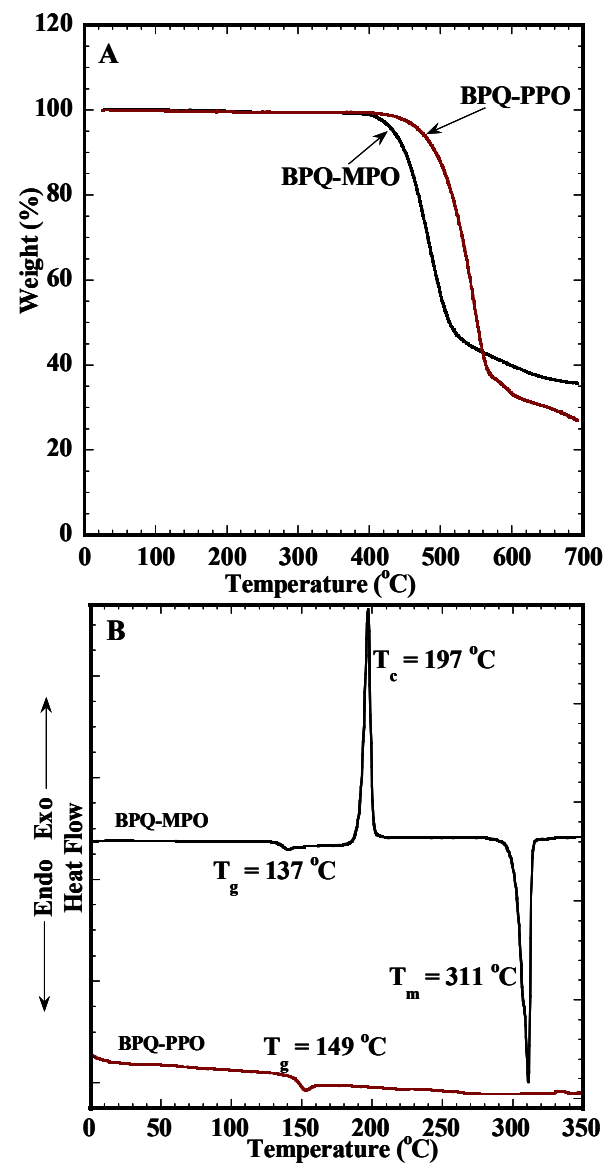

Figure S4. (A) TGA thermograms and (B) second-heating DSC scans of BPQ-PPO and BPQ-MPO. 


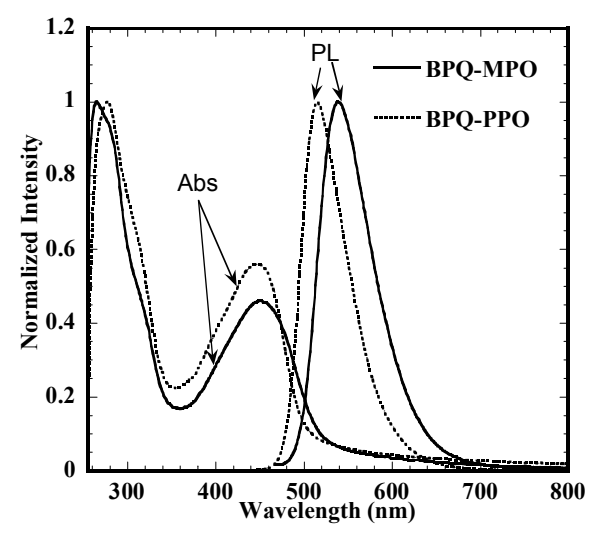

Figure S5. Absorption and PL emission spectra (420-nm excitation) of thermally evaporated thin films of BPQ-PPO and BPQ-MPO.
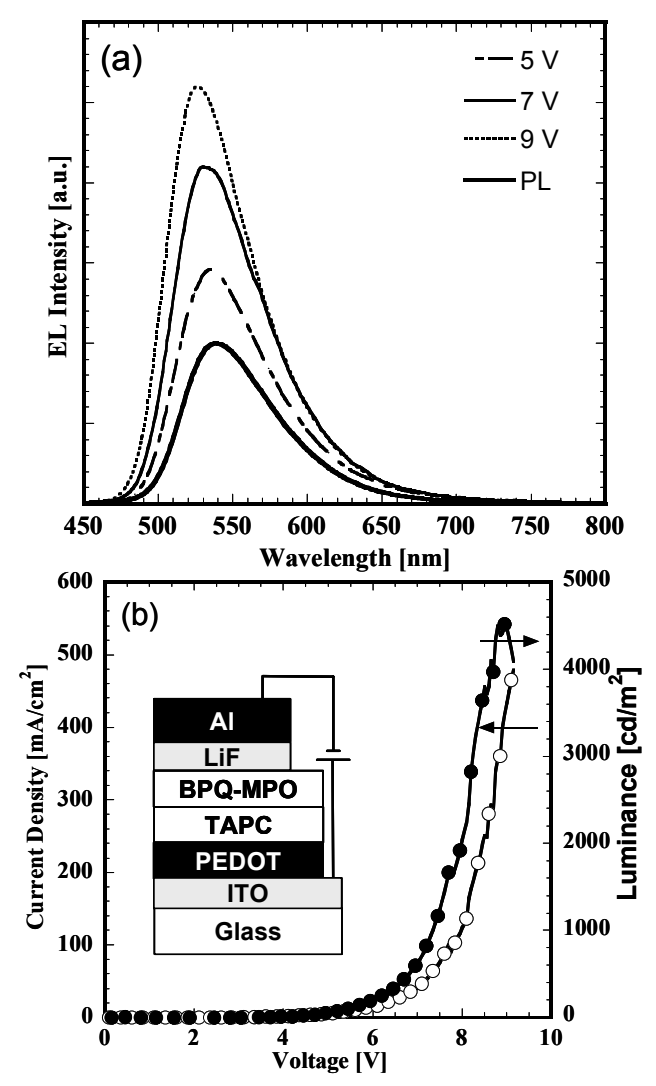

Figure S6. (A) EL spectra and PL spectrum of a BPQ-MPO OLED. (B) Current densityvoltage-luminance characteristics of the device shown in the inset. 